\title{
Relação entre grau de severidade de disfunção temporomandibular e a voz $* * * *$
}

\author{
Relationship between the severity of temporomandibular disorder \\ and voice
}

\begin{abstract}
Ana Maria Toniolo da Silva*
Marcela Forgiarini Morisso**

Carla Aparecida Cielo***
\end{abstract}

*Fonoaudióloga. Doutora em Distúrbios da Comunicação HumanaUniversidade Federal de São Paulo. Professor Adjunto do Departamento de Fonoaudiologia, Curso de Fonoaudiologia e do Programa de Pós-Graduação em Distúrbios da Comunicação Humana - Universidade Federal de Santa Maria. Endereço para correspondência: Rua Ângelo Bolson, 523 - Apto 301 - Santa Maria - RS CEP 97070-000

(ads11122@san.psi.br)

**Fonoaudióloga. Mestre em Distúrbios da Comunicação Humana da Universidade Federal de Santa Maria

***Fonoaudióloga. Doutora em Linguística Aplicada pela Pontifícia Universidade Católica do Rio Grande do Sul, Professor Adjunto do Departamento de Fonoaudiologia do Curso de Fonoaudiologia e do Programa de Pós-Graduação em Distúrbios da Comunicação Humana na Universidade Federal de Santa Maria.

****Pesquisa Realizada no Departamento de Fonoaudiologia e no Curso de Odontologia da Universidade Federal de Santa Maria.

Artigo de Pesquisa

Artigo Submetido a Avaliação por Pares

Conflito de Interesse: não

Recebido em 13.09.2006.

Revisado em 31.10.2006; 15.03.2007; 18.06.2007.

Aceito para Publicação em 18.07.2007.

\begin{abstract}
Background: temporomandibular dysfunction is one of the most complex disorders of the body, capable of unchaining alterations in the mandibular movements which in turn can cause damage not only to speech articulation but also to the quality of voice. In the literature, the relationship between the symptomatology severity levels of this dysfunction and their influence on vocal production has been scarcely studied. Aim: to verify the relationship between the symptomatology severity levels of temporomandibular dysfunction and vocal production. Method: participants of this study were 24 females, with ages between 16 and 56 years, who were submitted to an anamnesis index questionnaire (Fonseca et al., 1994), to odontological and otolaryngological examinations and to a hearing evaluation. Later, the participants were submitted to a voice recording, using a digital recorder, for a perceptiveauditive analysis of voice parameters such as: vocal type, resonance, quality of emission, pitch and loudness and for the analysis of the acoustic parameters of the wide and narrow band spectrography and of the Multi Dimensional Voice Program (MDVP) - Key Elementrics Real Time software. Results: considering the parameters of the perceptive-auditive evaluation, it was observed that only individuals with severe symptomatology presented a statistically significant decrease in loudness $(\mathrm{p}=0.013)$. The hoarse vocal quality was the most frequent type among the participants, with severities classified as mild and severe, followed by the breathy type. In the wide band spectrography, there was a statistically significant difference for the anti-resonance increase $(\mathrm{p}=0.013)$ in individuals with severe temporomandibular dysfunction. Conclusion: it was verified that the severity level causes a decrease in loudness, an increase of noise and alterations in voice resonance, interfering in the vocal quality of these individuals.
\end{abstract}

Key Words: Temporomandibular Joint; Roughness; Orofacial Pain; Spectrography.

\section{Resumo}

Tema: a disfunção temporomandibular é uma das desordens mais complexas do organismo capaz de desencadear alterações nos movimentos mandibulares que provocam prejuízos tanto na articulação da fala como na qualidade da voz. Na literatura a relação entre o grau de severidade da sintomatologia desta disfunção e a influência desta na produção vocal tem sido pouco estudada. Objetivo: verificar a relação entre o grau de severidade de sintomatologia da disfunção temporomandibular com a produção vocal. Método: participaram deste estudo 24 sujeitos, do gênero feminino, com idade variando entre 16 e 56 anos que foram submetidos à aplicação do questionário de índice anamnésico Fonseca et al. (1994), a exame odontológico, exame otorrinolaringológico e avaliação audiológica. Posteriormente os 24 sujeitos da pesquisa foram submetidos à gravação da voz, em gravador digital para posterior análise perceptivo-auditiva dos parâmetros da voz como: tipo vocal, ressonância, qualidade da emissão, pitch e loudness, e para análise dos parâmetros acústicos da espectrografia de banda larga, banda estreita e dos parâmetros acústicos por meio do Multi Dimensional Voice Program (MDVP) da Key Elementrics Real Time. Resultados: verificou-se que de todos os parâmetros da avaliação perceptivo-auditiva da voz o grau de sintomatologia severo apresentou significância estatística para diminuição da loudness $(\mathrm{p}=$ 0,013). A qualidade vocal rouca foi a que mais apareceu nos sujeitos com grau leve e severo, seguida pela soprosa. Na espectrografia de banda larga houve significância estatística para o aumento da antiressonância $(\mathrm{p}=0,013)$ no grau severo de disfunção temporomandibular. Conclusão: verificou-se que o grau de severidade ocasiona diminuição da loudness, aumento de ruído e alteração na ressonância da voz interferindo na qualidade vocal desses sujeitos.

Palavras-Chave: Articulação Temporomandibular; Rouquidão; Dor Orofacial; Espectrografia.

Referenciar este material como:

SILVA, A. M. T.; MORISSO, M. F.; CIELO, C. A. Relationship between the severity of temporomandibular disorder and voice 约 (original title: Relação entre grau de severidade de disfunção temporomandibular e a voz). Pró-Fono Revista de Atualização Científica, Barueri (SP), v. 19, n. 3, p. 279-288, jul.-set. 2007. 


\section{Introduction}

During the last years, the temporomandibular joint has been frequently studied in the SpeechLanguage Pathology field having in fact the responsibility of this field with the mandibular movements and with the efficiency of the stomatognatic functions that propitiate speech and voice clarity.

In the literature, the importance of the mandibular movements is very empathized regarding the speech articulation, and only few studies investigate the influence of the damage of the mandibular mobility at the vocal production.

According to Oliveira and Crivello (2004), the temporomandibular disorders affect the stomatognatic system as a whole, bringing the adaptation on these individuals, depending on the physiological tolerance of each one.

The temporomandibular disorders constitute a term that encloses a series of clinical problems involving, besides the chewing muscles, the articulation and other associated structures. At the same way, according to Barbosa (2003), the temporomandibular disorders do not only include any joint and stomatognatic muscles disharmony but also the presence of neck pain, the limitation of the mandibular movements and the articulatory noises. Stiesch-scholtz et al. (2003) believe that the temporomandibular disorder is characterized by several types of muscle and bone pain, a fact that makes this individuals to carry through a muscular adaptation.

In the literature, Magnusson et al. (2000) explain that at the temporomandibular dysfunctions the condition of muscles and bones, not only at the cervical region but also at the chewing muscles, are the greatest causes of non dental pain of the orofacial region. Other studies as the one conducted by Hara et al. (2000) believe that the functional and structural factors are united, characterize a multifatorial cause for the temporomandibular disorder origin.

It is important to mention that, in general literature, few are the articles that relate the presence of symptomatology of the temporomandibular disorder as the vocal profile of these individuals and not even point to the presence of vocal complaint as signs of this disorder.

When a temporomandibular diagnosis is discussed, the symptoms of this dysfunction, as the voice disorders, receive little attention and interest in the same way that almost none is the objective to investigate the relevance of this problem's degree regarding vocal production.

The possible relationship between the temporomandibular disorders and the phonation disorders was pointed, only in 1979, by Barnard, which suggested a possible relationship of the phonation problems as a consequence of a difficulty in the mandibular movements.

According to Behlau (2001), the temporomandibular disorder and the orofacial pain are problems that affects great part of the population and have as clinical signs the limitation of the mandibular movements, that may interfere in the acoustic of the voice. However, the studies regarding frequency and degree of the compromising of these movements and, by extension, of the temporomandibular joint evolved in muscular alteration related to voice are still only a few.

Camargo et al. (2001), verified that the alterations of the temporomandibular joint can directly influent the vocal production, specially, regarding the articulatory mechanisms, resonance, intensity and roughness of the voice increase. These same authors verified that the roughness is the vocal symptom that is more cited by the studied individuals presenting disorder diagnosis; and observed that the vocal complains increased according to the evolution stage of the disorder. Besides that, they verified that regarding the laryngeal structural aspects there was hyperemic predominance.

Oliveira and Crivello (2004) added that the occurrence of muscular disequilibrium during the voice production generates what is known by dysphony. Bianchini (2003) also verified that the human voice production presents direct relationship with the possibility of liberty of the mandibular movements, that are obtained by the mean of the temporomandibular joint. In the study about the interference possibility of the temporomandibular disorders at the voice and speech characterization of the subjects, it was observed that $60,8 \%$ of the subjects with temporomandibular disorder presented symptoms of excessive fatigue, pain and voice changes, after longer periods of speech.

Coelho (2001) investigated the voice of individuals presenting temporomandibular disorder by mean of a perceptive and auditory evaluation with the aim to verify the association of this function with the vocal profile. The results 
disclosed that the alterations on the scapular waist and head. Regarding voice, it were observed characteristics of roughness voice, blowness, besides alterations in aspects such as vocal attack, emission quality, modulation, resonance system, articulatory type, speech speed, vocal resistance and pitch. The author concluded that the individuals presenting temporomandibular disorder are pre made used to develop vocal alterations, with a relationship between the temporomandibular disorder and vocal alteration.

From these studies and from the necessity of more knowledge in the Speech-Language Pathology field regarding temporomandibular disorder and voice the theme of this research appeared. This way, the present study had as objective to verify whether there is a relationship between the symptomatology degree of temporomandibular disorder and the vocal production of this individuals, once, in the literature, individuals with temporomandibular disorder are pre made used to present vocal alterations.

\section{Methods}

This research was previously approved by the Gabinete de Projetos do Centro de Ciências da Saúde da Universidade Federal de Santa Maria (Cabinet of Projects of the Health Science Center of the Federal University of Santa Maria), RS (GAP/ CCS), under the protocol number 116/2004 and by the Comitê de Ética em Pesquisa da Instituição (Ethical Committee For Research of the Institution) by the protocol number 116 .

Twenty four subjects, of the female gender, with age ranging from 16-56 years old, that presented symptoms of temporomandibular disorder, without previous dentistry treatment or use of dental prothesis, absence of hearing loss, absence of stomatognatic functions and/or vocal pathologies were part of this study. Individuals that presented no pain during the touch of the chewing and neck muscles, individuals whom smoke, individuals with oral-facial-maxillary surgical historical, individuals with hormonal problems, absence of complaint and signs of temporomandibular dysfunction and that had previously attended Speech-Language Pathology therapy were excluded from this research. The selection of the

subjects occurred from the search for them through the Clínica Escola do Curso de Odontologia da Universidade Federal de Santa Maria (School Clinic of the Dentistry Course of the Federal University of Santa Maria). For all and each procedure an assent therm free and clarified previously approved by the Ethical and Research Committee of the origin institution following the ethical concerns demanded on the accomplishment of evaluations and experimentations with humans, according to resolution 196/96.

Initially, all subjects were submitted to the application of a questionnaire of anamnesis index that was constituted by ten questions referring to the principal complains and symptoms of the temporomandibular disorder developed by Fonseca et al. (1994). The questions were referring to the investigation of the pain presence, parafunctional habits, limitations of mandibular movements, articulatory noise, subjective perception of malocclusion and emotional tension. Previously to the application of the questionnaire, the subjects were informed of the possible answers alternatives contained on the same: "Yes", "No" and "Sometimes". The questions were read loud to a posterior answer of the evaluated individual and marking on the form. The subject was oriented to answer all the questions and, for each one of them only one answer should be chosen. In order to obtain the anamnesis index the values attributed to the answers were: Yes= ten points, $\mathrm{No}=\mathrm{Zero}$ points and Sometimes $=$ five points.

The classification of the severity degree of the symptomatology of the temporomandibular disorder was made as following: light from 20-40 points; moderated values between $45-65$ points and severe between $70-100$ points.

Later, the subjects were submitted to a clinical examination, according to Okeson (2000) in order to investigate the presence of pain to the touch of the intra and extra oral muscles of the temporomandibular joint. This clinical examination was made by a surgical dentist by mean of a unique firm pressure, with duration of 1 to 2 seconds over the main chewing muscles (anterior, medium and posterior temporal, superficial and profound masseter, medium pterygoideo, temporal) and over the muscles that supply secondary support as the neck ones (sternocleidomatoid, trapeze, posterior cervical muscles). During touch it was asked to the subject if he/she felt pain or only uncomfortable. During the investigation, the subjects were also submitted to the investigation of the presence of malocclusion and dental consuming in order to confirm the data founded over the questionnaire. The maximum buccal opening was measured with a plastic pachymeter, and it was considered a restrict buccal opening 
any distance less than $40 \mathrm{~mm}$, according to Okeson (2000). An auditory and otorhinolaryngological evaluation were also made, followed by a voice anamnesis and posterior recording of the voice for perceptive-auditory and acoustic voice analysis. The voice recording of the subjects was made individually. In this evaluation the subject was asked to stand, leave the arms along the body, and also asked to make a profound inhale and to emit the open vowel /a/ isolated and sustained in the usual frequency and intensity.

The data analysis of the perceptive and auditory evaluation of voice was made by three judges, Speech-Language Pathologists, being considered as final results the common opinion or the predominant among the analyzed data from the judges. The judgment were made individually, in an independent way, and the judges did not know about the vocal samples.

The acoustical analysis of the subjects 'voices of this research was made, in a private clinic, by na Speech-Language Pathologist, expert in the voice field, through the recording of the 24 voices, in a CD player. The Speech-Language Pathologist analyzed the voices with the Spectrum Graphic program from Kay Elemetrics-Real Time Spectrogram, Model 3700, version 2.30, in which it were extracted the spectrum graphics tracing of narrow band (EBE) (intensity of high frequencies, intensity of the entire vocal spectrum, presence of noise, definition of the harmonics, regularity of the tracing and anti-resonance). At the spectrum graphics of the wide band (EBL) it were extracted (intensity of the formants, intensity of the high frequencies, intensity of the entire vocal spectrum, presence of noise, wideness of the formant band, definition of the formants, regularity of the tracing, anti-resonance). For each of these acoustic parameters it were considered three items for marking: reduction, increase without alteration. The initial and final portions of the sustained emission of vowels were not considered because, according to the literature, it is in these portions that are present the biggest degrees of perturbation and instability and this way, may compromise the final results of this research. By mean of the Program Multi Dimensional Voice Profile (MDVP), from Kay Elemetrics, Model 5105, version 2.30, the parameters of the glottis signal were analyzed regarding the fundamental frequency and intensity (jitter e shimmer).

The data analysis of this research were submitted to statistical analysis and the number of the subjects was considered representative for the study. It was used the qui-squared test for independence with a significance level of 5\%. This way, the results founded at the perceptive-auditory and acoustic evaluations of the voice were related to the degree of the severity of the temporomandibular disorder, having that all the value founded on the results $p<0,05 \%$ was considered as a dependent variable of the symptomatology degree of temporomandibular disorder. The results, following, were distributed in graphics an tables.

\section{Results}

Graphic 1 shows the description of the sample to the severity degree of symptomatology of the temporomandibular disorder. It can be verified a greater number of subjects, presenting light symptomatology degree of the temporomandibular disorder.

GRAPHIC 1. Relative distribution of the number of subjects according to the severity degree of the symptomatology of the temporomandibular disorder.

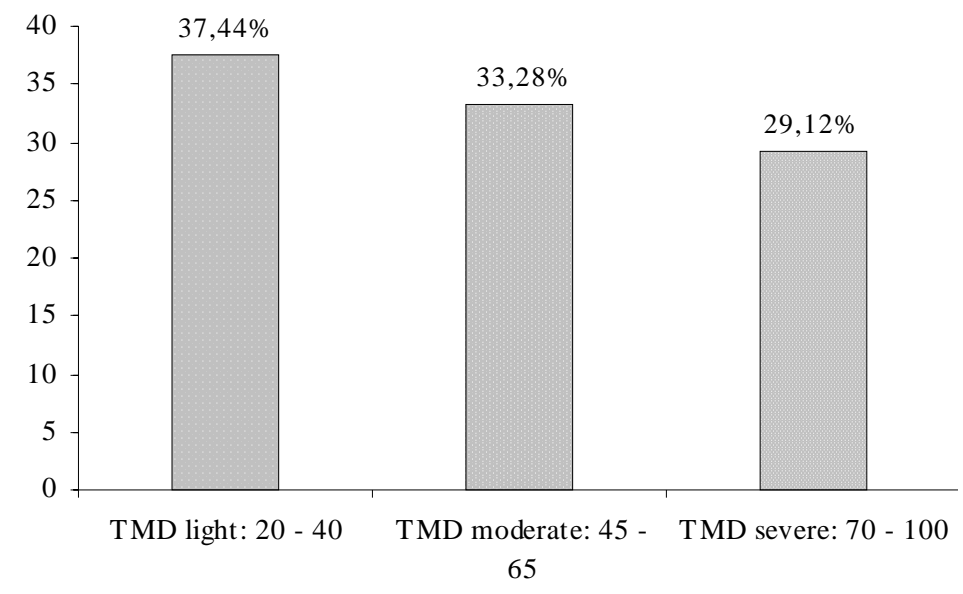

Of all the parameters of the perceptive-auditory evaluation of the voice analyzed was statistical significance $(p=0,001)$ for the decreasing of the loudness in the severe degree of symptomatology of the temporomandibular disorder. In the others parameters of the perceptive-auditory evaluation, the degree of the symptomatology of the temporomandibular dysfunction did not show interference, as it can be seen in Table 1. 
Regarding the acoustic parameters, of the Wide Band spectrum graphic presented bellow, the intensity in the whole vocal spectrum was the one that presented a greater number of subjects with alterations $(24,96 \%)$, in the severe degree of symptomatology, despite the non statistical significance, as it can be seen in Table 2 .

At the other acoustic parameters analyzed, in the Wide Band spectrum graphic, there was statistical significance $(p=0,0139)$ for the increase of the anti-resonance in the severe degree of symptomatology of the temporomandibular disorder, as it can be seen in Table 3 .

At the spectrum graphic of Narrow Band the acoustical parameters, tracing regularity and harmonic definitions presented greater number of subjects with alteration of the symptomatology degree light of the temporomandibular disorder
$(24,96 \%)$ and $(35,28 \%)$ respectively, despite of the non statistical significance. However, at the severe degree of symptomatology of the temporomandibular disorder, the acoustical parameters, intensity in the entire vocal spectrum and anti-resonance $(24,96 \%)$ and $(16,64 \%)$ respectively, presented greater number of subjects with alterations, despite the non statistical significance, as it can be seen in Table 4.

Of all the results of the acoustic parameters of the glottis source of the program Multi Dimensional Voice Profile (MDVP), none of them presented relationship with the degree of the symptomatology severity of the temporomandibular disorder. However, a greater number of subjects with light symptomatology of temporomandibular disorder, presented alterations in these acoustic parameters when compared to the degrees of symptomatology moderated and severe (Table 5).

TABLE 1. Relative distribution of the degree of the symptomatology of TMD regarding the parameters of the perceptive-auditory evaluation of the voice.

\begin{tabular}{|c|c|c|c|c|c|c|c|c|c|c|c|}
\hline & & \multicolumn{10}{|c|}{ PARAMETERS OF THE PERCEPTIVE-AUDITORY EVALUATION OF VOICE } \\
\hline \multirow{2}{*}{\multicolumn{2}{|c|}{ Degree of TMD }} & \multicolumn{2}{|c|}{ Vocal Type } & \multicolumn{2}{|c|}{ Resonance } & \multicolumn{2}{|c|}{$\begin{array}{l}\text { Quality of the } \\
\text { emission }\end{array}$} & \multicolumn{2}{|c|}{ Pitch } & \multicolumn{2}{|c|}{ Loudness } \\
\hline & & $N$ & $\%$ & $N$ & $\%$ & $N$ & $\%$ & $N$ & $\%$ & $N$ & $\%$ \\
\hline \multirow[t]{2}{*}{ LIGHT } & Normal & 4 & 16,64 & 4 & 16,64 & 1 & 4,16 & 8 & 33,28 & 9 & 37,44 \\
\hline & Alteration & 5 & 20,80 & 5 & 20,80 & 8 & 33,28 & 1 & 4,16 & 0 & 0 \\
\hline \multirow[t]{2}{*}{ MODERATE } & Normal & 5 & 20,80 & 3 & 12,48 & 5 & 20,80 & 7 & 29,12 & 8 & 33,28 \\
\hline & Alteration & 3 & 12,48 & 5 & 20,80 & 3 & 12,48 & 1 & 4,16 & 0 & 0 \\
\hline \multirow[t]{2}{*}{ SEVERE } & Normal & 2 & 8,32 & 2 & 8,32 & 3 & 12,48 & 3 & 12,48 & 2 & 8,32 \\
\hline & Alteration & 5 & 20,80 & 5 & 20,80 & 4 & 16,64 & 4 & 16,64 & 5 & 20,80 \\
\hline$p<0,05$ & & \multicolumn{2}{|c|}{$p=0,8092$} & \multicolumn{2}{|c|}{$p=0,8092$} & \multicolumn{2}{|c|}{$p=0,2516$} & \multicolumn{2}{|c|}{$p=0,0914$} & \multicolumn{2}{|c|}{$p=0,001 *$} \\
\hline
\end{tabular}

\footnotetext{
* There was statistical significance
} 
TABLE 2. Relative distribution of the degree of symptomatology of the TMD regarding the acoustic parameters of the Wide Band Spectrum Graphic.

\begin{tabular}{|l||l|l|l|l|l|l||l|l|l|l||}
\hline \multicolumn{2}{|l|}{ Wide Band } \\
\hline \hline
\end{tabular}

There was no statistical significance

TABLE 3. Relative distribution of the degree of symptomatology of the TMD regarding the acoustical parameters of the Wide Band spectrum graphic.

\begin{tabular}{|c|c|c|c|c|c|c|c|}
\hline \multicolumn{8}{|l|}{ Wide Band } \\
\hline \multicolumn{2}{|l|}{ TMD degree } & \multicolumn{2}{|c|}{ Formant definitions } & \multicolumn{2}{|c|}{ Tracing regularity } & \multicolumn{2}{|c|}{ Anti-resonance } \\
\hline & & $N$ & $\%$ & $N$ & $\%$ & $N$ & $\%$ \\
\hline \multirow[t]{2}{*}{ LIGHT } & Normal & 3 & 12,48 & 3 & 12,48 & 8 & 33,28 \\
\hline & Alteration & 6 & 24,96 & 6 & 24,96 & 1 & 4,16 \\
\hline \multirow[t]{2}{*}{ MODERATE } & Normal & 3 & 12,48 & 3 & 12,48 & 7 & 29,12 \\
\hline & Alteration & 5 & 20,80 & 5 & 20,80 & 1 & 4,16 \\
\hline \multirow[t]{2}{*}{ SEVERE } & Normal & 2 & 8,32 & 2 & 8,32 & 2 & 8,32 \\
\hline & Alteration & 5 & 20,80 & 5 & 20,80 & 5 & 20,80 \\
\hline$p<0,005$ & & \multicolumn{2}{|c|}{$p=0,9649$} & \multicolumn{2}{|c|}{$p=0,9649$} & \multicolumn{2}{|c|}{$p=0,0139 *$} \\
\hline
\end{tabular}

* There was statistical significance 
TABLE 4. Relative distribution of the symptomatology degree of TMD regarding the acoustical parameters of the Narrow Band spectrum graphic.

\begin{tabular}{|c|c|c|c|c|c|c|c|c|c|c|c|c|c|}
\hline \multicolumn{14}{|l|}{ Narrow Band } \\
\hline \multicolumn{2}{|l|}{ TMD degree } & \multicolumn{2}{|c|}{$\begin{array}{l}\text { Intensity of the high } \\
\text { frequencies }\end{array}$} & \multicolumn{2}{|c|}{$\begin{array}{l}\text { Intensity in the entire } \\
\text { vocal spectrum }\end{array}$} & \multicolumn{2}{|c|}{$\begin{array}{l}\text { Tracing } \\
\text { regularity }\end{array}$} & \multicolumn{2}{|c|}{$\begin{array}{l}\text { Presence of } \\
\text { noise }\end{array}$} & \multicolumn{2}{|c|}{$\begin{array}{l}\text { Harmonic } \\
\text { definitions }\end{array}$} & \multicolumn{2}{|c|}{$\begin{array}{l}\text { Anti- } \\
\text { resonance }\end{array}$} \\
\hline & & $N$ & $\%$ & $N$ & $\%$ & $N$ & $\%$ & $N$ & $\%$ & $N$ & $\%$ & $N$ & $\%$ \\
\hline \multirow[t]{2}{*}{ LIGHT } & Normal & 9 & 37,44 & 5 & 20,80 & 3 & 12,48 & 7 & 29,12 & 1 & 4,16 & 6 & 24,96 \\
\hline & Alteration & 0 & 0 & 4 & 16,64 & 6 & 24,96 & 2 & 8,32 & 8 & 33,28 & 3 & 12,48 \\
\hline \multirow[t]{2}{*}{ MODERATE } & Normal & 6 & 24,96 & 6 & 24,96 & 6 & 24,96 & 6 & 24,96 & 5 & 20,80 & 6 & 24,96 \\
\hline & Alteration & 2 & 8,32 & 2 & 8,32 & 2 & 8,32 & 2 & 8,32 & 3 & 12,48 & 2 & 8,32 \\
\hline \multirow[t]{2}{*}{ SEVERE } & Normal & 5 & 20,80 & 1 & 4,16 & 2 & 8,32 & 5 & 20,80 & 2 & 8,32 & 3 & 12,48 \\
\hline & Alteration & 2 & 8,32 & 6 & 24,96 & 5 & 20,80 & 2 & 8,32 & 5 & 20,80 & 4 & 16,64 \\
\hline$p<0,05$ & & \multicolumn{2}{|c|}{$p=0,2844$} & \multicolumn{2}{|c|}{$p=0,1586$} & \multicolumn{2}{|c|}{$p=0,4949$} & \multicolumn{2}{|c|}{$p=0,9585$} & \multicolumn{2}{|c|}{$p=0,3539$} & \multicolumn{2}{|c|}{$p=0,4163$} \\
\hline
\end{tabular}

There was no statistical significance

TABLE 5. Relative distribution of the symptomatology degree of the TMD regarding the acoustical parameters of the MDVP program.

\begin{tabular}{|c|c|c|c|c|c|c|c|c|c|c|c|c|c|}
\hline \multicolumn{14}{|l|}{$M D V P$} \\
\hline \multicolumn{2}{|l|}{ TMD degree } & \multicolumn{2}{|c|}{ Fo } & \multicolumn{2}{|c|}{ MFO } & \multicolumn{2}{|c|}{$P P Q$} & \multicolumn{2}{|c|}{$v F O$} & \multicolumn{2}{|c|}{$A P Q$} & \multicolumn{2}{|c|}{$N H R$} \\
\hline & & $N$ & $\%$ & $N$ & $\%$ & $N$ & $\%$ & $N$ & $\%$ & $N$ & $\%$ & $N$ & $\%$ \\
\hline \multirow[t]{2}{*}{ LIGHT } & Normal & 9 & 37,44 & 9 & 37,44 & 1 & 4,16 & 2 & 8,32 & 1 & 4,16 & 0 & 0 \\
\hline & Alteration & 0 & 0 & 0 & 0 & 8 & 33,28 & 7 & 29,12 & 8 & 33,28 & 9 & 37,44 \\
\hline \multirow[t]{2}{*}{ MODERATE } & Normal & 8 & 33,28 & 8 & 33,28 & 0 & 0 & 0 & 0 & 1 & 4,16 & 0 & 0 \\
\hline & Alteration & 0 & 0 & 0 & 0 & 8 & 33,28 & 8 & 33,28 & 7 & 29,12 & 8 & 33,28 \\
\hline \multirow[t]{2}{*}{ SEVERE } & Normal & 7 & 29,12 & 7 & 29,12 & 2 & 8,32 & 2 & 8,32 & 4 & 16,64 & 0 & 0 \\
\hline & Alteration & 0 & 0 & 0 & 0 & 5 & 20,80 & 5 & 20,80 & 3 & 12,48 & 7 & 29,12 \\
\hline$p<0,05$ & & - & & - & & & ,2451 & &, 2844 & & 06655 & |- & \\
\hline
\end{tabular}

There was no statistical significance. 


\section{Discussion}

At the perceptive-auditory evaluation of voice, of all the studied parameters, loudness was the only that presented a statistical significance relation $(\mathrm{p}<0,001)$ with the symptomatology degree of the temporomandibular disorder. The subjects classified with the severe degree of symptomatology of the disorder presented reduction in loudness, suggesting that there is a direct relationship between the severity degree with the voice intensity. This find agrees with the Austin (2006) study which verified that the smaller the buccal opening, or the movement of lower the mandible, the weaker is the vocal intensity. A author affirmation may also agree with the findings regarding the pitch of the voice of the subjects with moderate and severe symptomatology of temporomandibular dysfunction. These authors presented the pitch alteration justifying the findings of Lima et al. (2005) and Austin (2006) that refereed that the pitch of the voice increases according to a bigger movement of amplitude of the mandible; and at this study the altered pitch was found on the subjects with severe and moderate symptomatology of temporomandibular dysfunction, despite the non statistical significance. At the acoustic analysis of voice, the Wide Band Spectrum graphic, at the parameter antiresonance, presented statistical significance $(p<0,001)$ for the increase, on the subjects with symptomatology of severe degree of temporomandibular disorder. This results show that the subjects, of this study, with severe symptomatology show a tendency to present a smaller opening of the mouth, during phonation, because the presence of pain on the chewing muscles, taking to a increase in voice resonance. This finding suggests this relationship because the majority of the participants of this research $(n=23)$ did not presented buccal opening smaller than $40 \mathrm{~mm}$ and, only one participant presented reduction in the mouth maximum opening. This fact indicates that the probable presence of pain, presented by the subjects of this research over the chewing muscles, takes to a smaller buccal opening, suggesting, this way, to the perception of the hyper nasality of their voices. This finding also may be justified by Sousa et al. (2004) that verified, in individuals with symptomatology of temporomandibular disorder, that the soft palate is the element of the stomatognatic system that is less affected in this individuals. This way, it is believed that the subjects with severe degree of symptomatology of the temporomandibular dysfunction presented an increase of the voice resonance not because of the alteration of the velopharyngeal sphincter (VFS), however, because the presence of pain over the chewing muscles that hinder that them open widely the mouth. It is suggested that the presence of pain over the chewing muscles is the cause of the interference over the voice loudness and resonance; therefore $(n=23)$ subjects of this study did not presented buccal opening smaller than $40 \mathrm{~mm}$, showing that there was the presence of pain over the chewing muscles, presented during touch, that brought such alterations in their voices. In the literature, Bataglion et al. (2003), Celic et al. (2004), affirmed that the subjects with temporomandibular disorders shown more restrictive movements on the mandibular activity, when compared to non symptomatic individuals. Those finding also contributes to the results of this research, which suggest that the individuals with symptomatology of temporomandibular disorder are strong candidates to develop vocal alterations because they have constant contraction of the muscles, despite not having reduction of the maximum measure of the buccal opening. The findings of Ramos et al. (2003) added that despite the mechanisms that are responsible for the development of this disorder are not clarified, it is possible to unite some, among them the hyper muscular activity. This way, Carrara-de Angelis and Cervantes (2001) added that the vocal quality is formed by laryngeal and supra laryngeal structures, being resonance part of vocal quality. Thus it is suggested that the severe degree of symptomatology of the temporomandibular disorder, interferes over the voice resonance, being able to take to the alteration in the voice quality of these subjects.

These findings cited above come to find literature that refers that the individuals with symptomatology of temporomandibular disorders, present a smaller buccal opening because of the presence of pain over the the muscles which brings to a reduced loudness. In a study made by Mangili et al. (2006) it was observed as a complaint of the hypertrophy of the masseter muscle, the difficulty of buccal opening and the muscular rigidity. This conclusion agrees with the findings of this research, which suggests that the difficulty regarding the mandibular amplitude, in the subjects with severe degree of symptomatology of the 
temporomandibular disorder, or by the presence of pain over the temporomandibular joint muscles, interfering, this way, on the voice acoustics. Another study conducted by Bolzan (2002) observed the existence of the correlation between the mouth opening smaller than $40 \mathrm{~mm}$ with the presence of unglued disc. However, in the findings of this research, all evaluated subjects did not presented reduction of the buccal opening, suggesting the interference of muscular pain over the voice quality of these subjects and, not only by problems of the joint disc, as generally is cited in the literature. Yi et al. (2002), also refer that the tension of the muscle of the subjects with symptomatology of temporomandibular disorder brings problems regarding the movements amplitude of the phonoarticulatory organs and also the reduction of the buccal opening as consequence of the muscular pain that occurs in these individuals in order to not increase the length of the muscle and, consequently, the pain. Yavich (2002) explains that in the cases of temporomandibular mandible asymmetry create tensions over the muscles involved, because the muscles of the temporomandibular joint try to correct the distortions, making movements with the aim to occlude the teeth and bringing the muscles to a stage of constant contraction. A recent study made by Oliveira et al. (2003) and Taboada et al. (2004) investigate the impact of the pain over the individuals with temporomandibular disorder. The authors verified that on people with severe disorder there is the impact of the pain in their lives, referring the relationship of the pain and the reduction of the mandibular amplitude with the degree of the temporomandibular dysfunction.

This way, the fact of the loudness being reduced by the severity degree of the temporomandibular disorder, these subjects tend to make a bigger effort to speak overloading, this way, the structures supra laryngeal and bringing to a vocal fatigue. The literature adds that these individuals end to develop improper adjustment of the supra hyoid musculature, taking to the vocal fatigue (Behlau, 2001; Bianchini, 2003).

However, the presence of the symptomatology of the light degree of temporomandibular disorder interferes more on the presence of the noise than properly on loudness and on voice resonance. This way, it is suggested that on the light symptomatology, thanks to the smaller number of symptoms, these would interfere only on the tracing regularity and on the harmonic definitions because, possible, these subjects might have a bigger mouth opening. Studies also refer that the evolution of the symptomatology degree of the disorder is variable, being hard to follow this evolution, justifying, this way, these findings on the subjects with light symptomatology when compared to the moderate or severe degree (Bevilacqua-Grossi et al., 2006). However, according to Bhuta et al. (2004) the rough has a relationship with the increasing of the harmonics on the findings of the spectrum graphic of Narrow Band, agreeing with the findings of the rough vocal type on the subjects of this research. Another relationship established, in this research, that might justifies the probable relationship of the degree of symptomatology of the disorder and the vocal production is regarding the presence of temporomandibular disorder and corporal alteration. The temporomandibular joint is directly related to the cervical and scapular region. The literature adds that the hyperactivity of the chewing muscles brings to an head categorization, and that the postural alterations presents a relationship with the temporomandibular disorders (Lima et al., 2004). The Fisher (2006) study also justifies these findings, because it suggested that a close relationship between the temporomandibular disorder and the pain at the cervical muscles, which brings these subjects to refer tension. From these studies, the present research suggests the probable relationship of the symptomatology of the temporomandibular disorders with the voice quality alterations founded on the studied subjects. Such as, according to Oliveira and Crivello (2004), the increase of the muscular activity involved with the phone articulatory production contributes to the increase of the occurrence of the light temporomandibular disorder, which possible takes to the occurrence of alterations on voice quality, that is, the presence of rough, reduced loudness and altered resonance. Another study that comes to this findings is the Cestari and Camparis (2002) one. This study concluded that the individuals with symptomatology of temporomandibular dysfunction present exaggerated tension, and such behavior might influent on the cervical tension and, consequently, will alter the voice of these individuals. Another study conducted by Amantéa et al. (2004), in order to verify the interference of the bad posture on the temporomandibular disorder verified the existence of the relationship between temporomandibular disorder and alterations on corporal posture, suggesting postural deviations such as head anterioziation, which might take to posterior voice alterations of these subjects. 
The analyzed parameters on the Program Multi Dimensional Voice Profile (MDVP), from Kay Elemetrics, do not present relationship with the severity degree of the symptomatology of temporomandibular disorder.

This way, the subjects with symptomatology of temporomandibular disorder present greater tendency to present functional dysphony.

\section{Conclusion}

Considering that the alterations founded on the vocal productions of the subjects with symptomatology of temporomandibular disorder, from this study, and relating it with the severity degree of symptomatology of temporomandibular disorder it is concluded that:

. the severity degree occasions the decreasing of loudness, and alteration on the voice resonance, interfering over the vocal quality of these subjects; - as greater the severity degree of the symptomatology of the temporomandibular disorder, greater will be its influence on loudness and on voice resonance;

. the severity degree of symptomatology of the temporomandibular disorder has greater tendency to influence on the filter than on the glottis fountain;

. the increase of the anti-resonance showed the direct relationship with the severity degree of symptomatology of the temporomandibular disorder;

. the individuals with a severe degree of symptomatology of temporomandibular disorder present greater tendency to have functional dysphony.

This way, it is taken into consideration the importance of the evaluation of the temporomandibular joint, such as, the investigation of the presence of symptomatology of disorder in patients with vocal complaints, such as, in patients that are receiving therapy only at the oral motricity field.

It is suggested the carry through of new studies, with individuals that present reduction of buccal opening, caused by intra-joint problems, since the majority of the sample presented buccal opening inside the overall standard, however that because the presence of pain on the chewing muscles reduced this opening during vocal emission.

\section{References}

AMANTÉA, D. V.; NOVAES, A. P.; CAMPOLONGO, G. D. A importância da avaliação postural no paciente com disfunção da articulação temporomandibular. Acta Ortop. Bra., São Paulo, v. 12, n. 3, p. 155-159, jul.-set. 2004.

AUSTIN, S. F. Jaw opening in novice and experienced classically trained singers. J. Voice, Texas, v. 21, n. 1, p. 72-79, jan. 2006.

BARBOSA, G. A. S. Recursos fisioterápicos disponíveis para o tratamento das disfunções temporomandibulares, J. Bras. Oclus. ATM Dor Orofac., São Paulo, v. 3, n. 6, p. 311-319, set. 2003

BATAGLiON, C.; CORONATTO, E. A. S. DE; BATAGLION, A.; ZUCCOLOTTO, M. C. C.; CHAGURI, N. A.; MENEZES, F. B. Estudo da amplitude de movimentos mandibulares em pacientes com disfunção temporomandibular após a utilização de placa oclusal miorrelaxante, RPG R. Pos-Grad., São Paulo, v. 10, n. 1, p. 19-24, jan.-mar. 2003.
BEHLAU, M. S. Avaliação da voz. In: BEHALU, M. S. Voz: o livro do especialista I. Rio de Janeiro: Revinter, 2001. cap. 3, p. 91-172.

BEVILAQUA-GROSSI, D.; CHAVES, T. C.; OLIVEIRA, A. S.; MONTEIRO, P. V. Anamnetic index severity and signs and symptoms of TMD. R. Cran., São Paulo, v. 24, n. 2, p. 112-118, apr. 2006.

BHUTA, T.; PATRICK, L.; GARNETT, J. D. Pereptual evaluation of voice quality and its correlation with acoustic measurements. J. Voice, Texas, v. 18, n. 13, p. 299-304, sep. 2004.

BIANCHINI, E. M. G. Verificação da interferência das disfunções da ATM na amplitude e velocidade do movimento mandibular durante a fala por meio da eletrognatografia. R. Dent. Press Ortodont. Ortop. Fac., Maringá, v. 8, n. 3, p. 109-115, maio-jun. 2003. 
BOLZAN, M. C. Estudo da correlação entre sinais clínicos e achados imagenológicos na ressonância magnética da articulação temporomandibular. 2002. 47 f. Dissertação (Mestrado em Odontologia) - Universidade Federal de São Paulo, São Paulo.

CAMARGO, Z. A.; RODRIGUES, K. A.; SANTOS, S. A. DOS. Relação entre sintomatologia da desordem vocal e da alteração da articulação temporomandibular. In: FERREIRA, L. P.; COSTA, H. O. Voz ativa falando sobre a clínica fonoaudiológica. São Paulo: Roca, 2001. artigo 19, p. 237-249.

CARRARA DE ANGELIS, E.; CERVANTES, O.; ABRAHÃO, M. Necessidade de medidas objetivas da função vocal: avaliação acústica da voz. In: FERREIRA, L. P.; COSTA, H. O. Voz ativa, falando sobre a clínica fonoaudiológica. São Paulo: Roca, 2001. Artigo 5, p. 5370 .

CELIC, R.; JEROLIMOV, V.; ZLATARIC, D. K. Relationship of slightly limited mandibular movements to temporomandibular disorders. Braz. Dent. J., Ribeirão Preto, v. 15, n. 2, p. 151-154, jun. 2004.

CESTARI, K.; CAMPARIS, C. M. Fatores psicológicos: sua implicação no diagnóstico das desordens temporomandibulares. J. Bras. Fonoaudiol., Curitiba, v. 3, n. 12, p. 243-249, jul.-set. 2002.

COELHO, T. T. T. Análise perceptivo-auditiva da voz de indivíduos com disfunção temporomandibular. 2001. 126 f. Dissertação (Mestrado em Distúrbios da Comunicação)Departamento de Fonoaudiologia, Universidade Tuiuti do Paraná, Curitiba.

FISHER, D. J. The association of temporomandibular disorder pain with history of head and neck injury in adolescents. J. Orofac. Pain, Canada, v. 20, n. 3, p. 191198, summer. 2006

FONSECA, D. M.; BONFANTE, G.; VALE, A. L.; FREITAS, F. S. T. Diagnóstico pela anamnese da disfunção craniomandibular. R. Gaúcha de Odontol., Porto Alegre, v. 42, n. 1, p. 23-28, jan.-fev. 1994.

HARA, B. E.; CAMARGO, F. G.; ATTIZZANI, A. Sinais e sintomas das disfunções temporomandibulares em crianças. R. Odontol. USF, Bragança Paulista, v. 16, n. 1, p. 91-102, dez. 2000.

LIM, M.; BONES. P. Vowel effect on glottal parameters and the magnitude of jaw opening. New Zedan, v. 1, n. 4, jun. 2005. Disponível em: 〈www.pubmed.gov>. Acesso em: 04 nov. 2005.

LIMA, E. C. B. DE; GONÇALVES, E. C.; REIS, A. C. Treino de postura em pacientes portadores de disfunções temporomandibulares. Reab., v. 6, n. 24, p. 55-59, jul.set. 2004.

MAGNUSSON, T.; EGERMARK, I.; CARLSSON, G. E. A longitudinal epidemiologic study of signs and symptoms of temporomandibular disorders from 15 to 35 years of age. J. Orofac. Pain, Canada, v. 4, n. 14, p. 310-319, jan. 2000 .
MANGILLI, L. D.; RODRIGUES, C. S.; CAMPIOTTO, A. R. A intervenção fonoaudiológica no pós-operatório da hipertrofia benigna do músculo masseter. R. Dent. Press Ortodon. Ortop. Fac., Maringá, v. 11, n. 2, p. 103-109, mar.-abr. 2006.

OKESON, J. P. Avaliação das disfunções temporomandibulares. In: OKESON, J. P. Tratamento das desordens temporomandibulares e oclusão. São Paulo: Artes Médicas, 2000. cap. 4.

OLIVEIRA, A. S. DE; BERMUDEZ, C. C.; SOUZA, R. A. DE; SOUZA, C. M. F.; DIAS, E. M.; CASTRO, C. E. S. C.; BERZIN, F. Pain impact on life of patients with temporomandibular disorder. J. Appl. Oral Sci., Bauru, v. 11, n. 2, p. 138-143, jun. 2003.

OLIVEIRA, M. F. R.; CRIVELLO, J. R. O comportamento da movimentação mandibular em pacientes com disfonia funcional e organofuncional. J. Bras. Fonoaudiol., Curitiba, v. 5, n. 19, p. 110-117, jan.-mar. 2004.

RAMOS, D. S. P.; SAUERESSIG, N. S.; LIMA, E. M. DE. Etiologia dos estalidos da articulação temporomandibular: uma revisão da literatura. $R$. Odontol. Ci., São Paulo, v. 18 , n. 41, p. 299-305, jul.-set. 2003.

SOUSA, D. F. M. DE; CORREIA, F. A. S. DOS. Distúrbios fonoaudiológicos relacionados à disfunção da articulação temporomandibular: estudo prospectivo. R. Bras. Cir. Periodont., Rio de Janeiro, v. 1, n. 3, p. 209-211, jul.-set. 2003.

STIESCH-SCHOLTZ, M.; FINK, M.; TSCHERNITSCHEK. H. Comorbidity of internal derangement of the temporomandibular joint and silent dysfunction of the cervical spine. R. J. Oral Rehab., Grã Bretanha, v. 30, n. 4, p. 386-381, 2003.

TABOADA, A. O.; GÓMEZ-GUTIÉRREZ, Y. L.; TABOADA, A. S.; MENDOZA-NÚNEZ, V. M. Prevalencia de signos y síntomas de los trastornos temporomandibulares en un grupo de adultos mayores. $R$. ADM J. Mexican Dent. Assoc., México, v. 61, n. 4, p. 125-129, jul.-ago. 2004.

YAVICH, L. G. Paciente com disfunção temporomandibular apresentando assimetria condilar e micronódulos no terço anterior das pregas vocais. J. Bras. Fonoaudiol., Curitiba, v. 3, n. 12, p. 190-197, jul.-set. 2002.

YI, L. C.; GUEDES, Z. C. F.; VIERIA, M. M. Relação da postura corporal com a disfunção da articulação temporomandibular: hiperatividade dos músculos da mastigação. Fisioter. Bras., São Paulo, v. 4, n. 5, p. 341347, set.-out. 2003.

ZAFAR, H. Integrated jaw and neck function in man: studies of mandibular and head-neck movements during jaw opening-closing tasks. R. Sweed. Dent. J. Suppl., Sweden, v. 143, s. n., p. 1-41, 2000. Disponível em: <www.pubmed.gov>. Acesso em: 04 nov. 2005. 